\title{
Analysis of Junior High School Student's Mathematical Reasoning Ability in Solving Non-routine Problems on Material of Two-variable Linear Equation Systems
}

\author{
Nurul Pratiwi ${ }^{1}$, Nyimas Aisyah ${ }^{2 *}$, Ely Susanti ${ }^{3}$, Weni Dwi Pratiwi ${ }^{4}$ \\ ${ }^{1}$ Student of Mathematical Education, Universitas Sriwijaya, Palembang, Indonesia \\ ${ }^{2,3,4}$ Department of Mathematical Education, Universitas Sriwijaya, Palembang, Indonesia \\ *Corresponding author.Email: nys_aisyah@yahoo.co.id
}

\begin{abstract}
Reasoning ability encourages students to think logically, so it is a very important part in learning process. This qualitative descriptive study aims to determine the mathematical reasoning ability of Junior High School students in solving non-routine problems of the two-variable linear equation systems material. The subjects were 6 students of class VIII.7 SMP Negeri 17 Palembang. Due to Covid-19, the research was conducted online using test and interviews, and analyzed descriptively. The results showed that of the 7 indicators of mathematical reasoning ability used, high-capable subjects fulfill almost all indicators. Indicators are not fulfilled in namely posing an assumption, perform mathematical manipulation, draw conclusions, compile evidence, provide reasons or evidence for the correctness of the solution to problem 1 and find patterns or properties of mathematical phenomena that will be generalized to problem 2. Indicators that are not fulfilled in medium-capable are perform mathematical manipulation, draw conclusions, compile evidence, provide reasons or evidence for the correctness of the solution and find patterns or properties of mathematical phenomena that will be generalized to problem 2. Students with low-capable still not dominant and only permit indicators to present oral, written, picture and diagram math statement and draw conclusions from those statements.
\end{abstract}

Keywords: Reasoning abilities, problem solving, linear equation system.

\section{INTRODUCTION}

Students' mathematical reasoning abilities play a major role in the achievement of mathematics learning $[1,3]$. Mathematical reasoning is the ability to understand mathematics in a logical way in order to form a conclusion based on facts and relevant sources [2, 4, 28]. Mathematical reasoning skills help students to conclude and prove a statement, build new ideas and solve mathematical problems [5]. This ability can train students to use their knowledge to think logically and systematically, examine a statement and finally solve a problem [6].

With reasoning students will use the rules, properties and logic of mathematics to understand and understand mathematical concepts and obtain the truth in mathematics and get a correct conclusion [6]. So it can be said that reasoning encourages students to think logically in making conclusions by following existing provisions and statements and making new statements that are proven true so that they can solve problems faced by students.

The world of mathematics requires mathematical reasoning to solve problems because reasoning encourages us to go through a logical thinking process [6, 7]. One of the descriptions of core competencies in the skill aspect is that students are required to demonstrate critical reasoning skills, that is, students do not only have the ability to count but the ability to think logically and critically in solving routine and non-routine problems [8]. NCTM states that improving students' mathematical reasoning abilities is one of the goals of learning mathematics [24]. So that mathematical reasoning skills are very important to develop because if not, then mathematics will only be material that follows and imitates existing procedures without being meaningful. 
Students are said to have mathematical reasoning abilities if students are able to (1) make calculations based on applicable rules, (2) draw general conclusions based on visible mathematical processes, (3) make assumptions, (4) draw conclusions based on similar mathematical processes, and (5) ) checks the validity of an argument [1, 9].

However, the fact that occurs in the field is that the reasoning ability of students in learning mathematics is still very low $[9,10]$. The low ability of students' mathematical reasoning becomes a problem that occurs in the learning process characterized by the low ability of students to understand and analyze concepts, use a method and draw conclusions $[11,12]$.

Most of the students have difficulty when dealing with mathematical problems that involve reasoning because students are still accustomed to memorizing [13]. The description of the mathematics learning process so far is that the teacher only gives questions that emphasize concept understanding, while higher thought processes including reasoning are rarely given [14]. Students have difficulty solving non-routine questions because the majority of learning only adopts routine questions and source books [15, 29, 30]. From this, it can be seen that so far students' reasoning has not been trained, students tend to just memorize and use the formulas that have been given by the teacher so that when students are faced with higher-level questions, students have difficulty solving them.

Previous research has shown students' low reasoning skills when the teacher gives questions on linear equation system material [11, 27]. Two-variable linear equation system is material learned in junior high school and becomes a concept that is difficult to understand by students because students' mathematical reasoning skills in SPLDV material are still low [11, 18]. Students make many mistakes in solving SPLDV problems, for example in changing to a mathematical model and incorrectly performing the solving procedure [19]. In addition, many students still have difficulty identifying variables and determining their solutions because they have not mastered SPLDV well [20, 21].

For that, it is necessary to make changes in learning, namely by getting students to work on non-routine questions. Non-routine questions can be used in learning to see the extent of students' reasoning abilities [22]. Problem solving problems or so-called non-routine problems are problems with the solving process that do not use ordinary procedures or problems that contain challenges to solve which require relatively longer time than routine problems [23]. Presenting non-routine questions to students means getting them used to applying various mathematical concepts in new situations and when students get used to non-routine questions, they will easily solve routine problems [25, 26]. That is, giving non-routine questions when learning mathematics is very necessary in order to improve students' abilities in learning mathematics and can be used in everyday life.

Given the importance of students 'mathematical reasoning, it is necessary to carry out an in-depth analysis of students' mathematical reasoning abilities. This analysis is in the form of students 'mathematical reasoning abilities in solving problem solving problems or non-routine questions as well as students' difficulties and mistakes in doing mathematical reasoning.

\section{METHOD}

This study is a qualitative descriptive research with the focus is the mathematical reasoning ability of Junior High School students in solving non-routine problems with the two-variable linear system (SPLDV) material. Due to pandemic condition, this research was conducted online with video lessons by Youtube, Whatsapp Group and Zoom Meetings. The subjects in this study were 6 students of class VIII.7 SMP Negeri 17 Palembang with high, medium and low ability categories. The data collection techniques used were tests and interviews. The tests were given in the form of 3 problem solving questions of descriptions of the SPLDV material which had been adjusted to the indicators of students 'mathematical reasoning abilities, while interviews were conducted to deepen the analysis of students' reasoning abilities by asking questions that were in accordance with the indicators. Table 1 shows the indicators used in this study.

Table 1. Indicators of mathematical reasoning.

\begin{tabular}{|l|l|}
\hline \multicolumn{1}{|c|}{ Indicator } & \multicolumn{1}{|c|}{ Descriptor } \\
\hline $\begin{array}{l}\text { Present oral, } \\
\text { diagram math } \\
\text { statement }\end{array}$ & $\begin{array}{l}\text { Able to explain the problems } \\
\text { from the questions given, be } \\
\text { able to determine and identify } \\
\text { the information contained in the } \\
\text { questions, namely knowing } \\
\text { what is known and asked from } \\
\text { the questions. }\end{array}$ \\
\hline $\begin{array}{l}\text { Possing an } \\
\text { assumption }\end{array}$ & $\begin{array}{l}\text { Able to develop arguments and } \\
\text { strategies to determine the } \\
\text { steps for completion and the } \\
\text { elements used. }\end{array}$ \\
\hline $\begin{array}{l}\text { Perform } \\
\text { mathematical } \\
\text { manipulation }\end{array}$ & $\begin{array}{l}\text { Able to use certain methods in } \\
\text { solving problems. }\end{array}$ \\
\hline Draw conclusions, \\
compile evidence,
\end{tabular}




\begin{tabular}{|l|l|}
\hline $\begin{array}{l}\text { provide reasons or } \\
\text { evidence for the } \\
\text { correctness of the } \\
\text { solution. }\end{array}$ & $\begin{array}{l}\text { determined in carrying out the } \\
\text { steps to solve it appropriately. }\end{array}$ \\
\hline $\begin{array}{l}\text { Drawing conclusion } \\
\text { from the statement }\end{array}$ & $\begin{array}{l}\text { Able to use the knowledge to } \\
\text { produce a thought in } \\
\text { accordance with the problems. }\end{array}$ \\
\hline $\begin{array}{l}\text { Checking the } \\
\text { validaty of an } \\
\text { argumen }\end{array}$ & $\begin{array}{l}\text { Able to re-examine problems } \\
\text { and investigate the truth of the } \\
\text { statements. }\end{array}$ \\
\hline $\begin{array}{l}\text { Find patterns or } \\
\text { properties of } \\
\text { mathematical } \\
\text { phenomena to } \\
\text { make }\end{array}$ & $\begin{array}{l}\text { Able to find patterns or } \\
\text { groperties of a problem and can } \\
\text { be used to solve new situations } \\
\text { so that students are able to } \\
\text { draw valid conclusions. }\end{array}$ \\
\hline
\end{tabular}

Data analysis was performed using descriptive methods by describing students' mathematical reasoning abilities that appeared on test results, interviews and researcher notes. The questions used is a non-routine problem that has been adjusted to the indicator of mathematical reasoning ability. The following are questions used in this study:

Table 2. Problem solving two-variable linear equation system material.

\begin{tabular}{|c|l|}
\hline No. & \multicolumn{1}{|c|}{ Problem } \\
\hline 1 & \begin{tabular}{l} 
A grandfather named Andi has a granddaughter \\
named Nurul. 3 years ago, Nurul's age was $\frac{1}{6}$ of \\
Nurul's age is $\frac{1}{3}$ of grandfather's age, then how \\
old will Nurul and Grandpa be in the next 5 \\
years? And is it true that they are now 100 years \\
old? \\
\hline 2
\end{tabular} \\
$\begin{array}{l}\text { Ani and Ina go to a bookstore. At the bookstore, } \\
\text { everyone who has a member card will be given a } \\
\text { discount of IDR 5,000 / book. That day, the } \\
\text { bookstore's birthday and offers each of the same } \\
\text { types of books at the same price. Here are some } \\
\text { book prices at the shop. }\end{array}$ \\
\hline
\end{tabular}

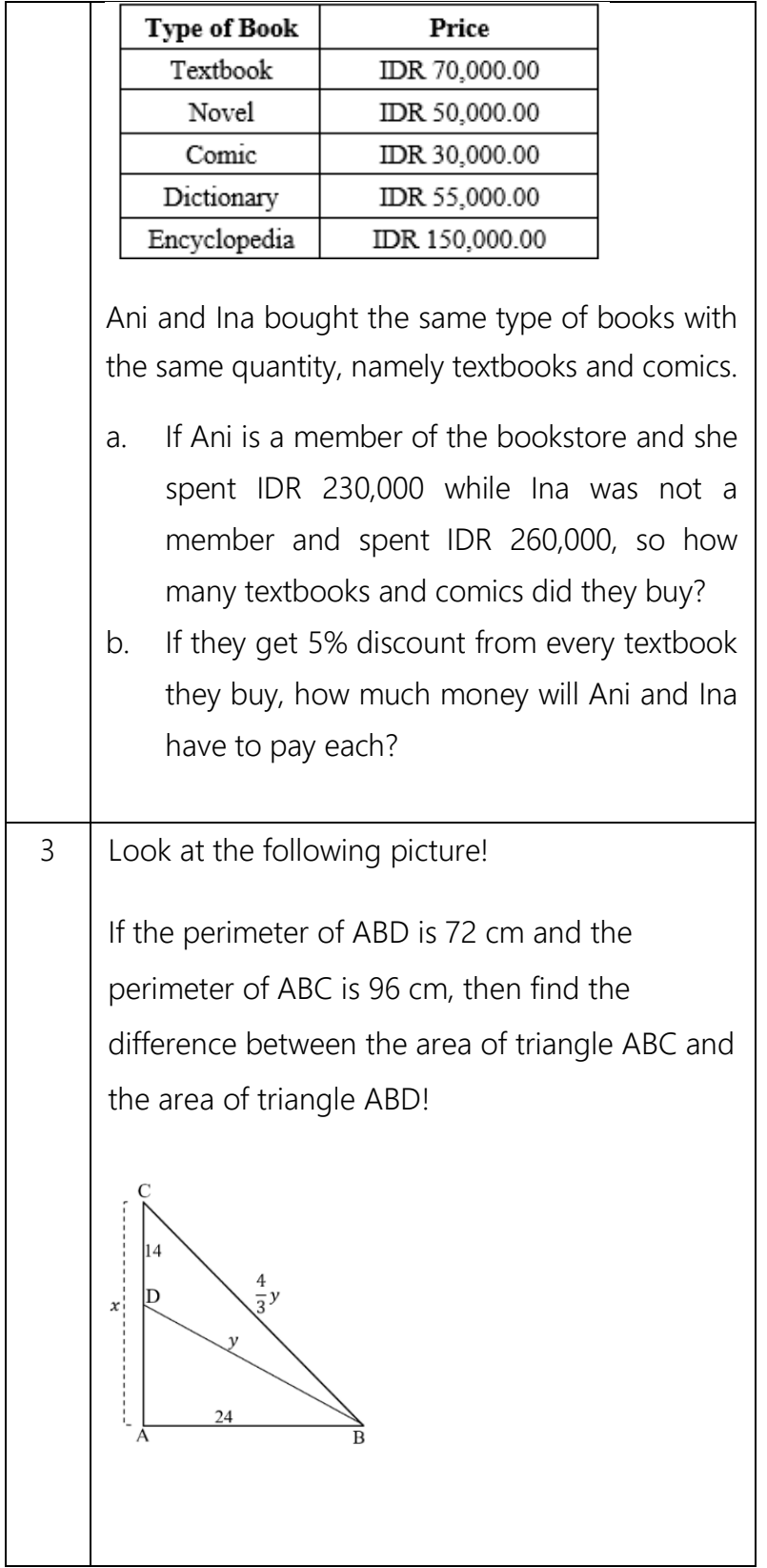

\section{RESULT AND DISCUSSION}

The results of the analysis were obtained from test questions and interviews. Students work on 3 essay questions for 45 minutes and are supervised by researcher via Zoom Meetings. After the researcher gets the test results, the researcher checks their work steps and pays attention to the indicators that appear. Furthermore, researcher conducted interviews to deepen the analysis on one by one the subjects via Zoom Meetings. The results of the analysis of test and interview questions can be seen in Table 3 below. 
Table 3. The results of the analysis of test questions and interview.

\begin{tabular}{|c|c|c|c|c|c|c|c|c|}
\hline \multirow{2}{*}{ Subject } & \multirow{2}{*}{$\begin{array}{l}\text { Question } \\
\text { Number }\end{array}$} & \multicolumn{7}{|c|}{ Indicator } \\
\hline & & 1 & 2 & 3 & 4 & 5 & 6 & 7 \\
\hline \multirow{3}{*}{ RO } & 1 & $\checkmark$ & $x$ & $\checkmark$ & $\checkmark$ & $\checkmark$ & $\checkmark$ & $\checkmark$ \\
\hline & 2 & $\checkmark$ & $\checkmark$ & $\checkmark$ & $\checkmark$ & $\checkmark$ & $\checkmark$ & $\checkmark$ \\
\hline & 3 & $\checkmark$ & $\checkmark$ & $\checkmark$ & $\checkmark$ & $\checkmark$ & $\checkmark$ & $\checkmark$ \\
\hline \multirow{3}{*}{ AS } & 1 & $\checkmark$ & $\checkmark$ & $x$ & $x-$ & $\checkmark$ & $\checkmark$ & $\checkmark$ \\
\hline & 2 & $\checkmark$ & $\checkmark$ & $\checkmark$ & $\checkmark$ & $\checkmark$ & $\checkmark$ & $x$ \\
\hline & 3 & $\checkmark$ & $\checkmark$ & $\checkmark$ & $\checkmark$ & $\checkmark$ & $\checkmark$ & $\checkmark$ \\
\hline \multirow{3}{*}{ DKJ } & 1 & $\checkmark$ & $\checkmark$ & $\checkmark$ & $\checkmark$ & $\checkmark$ & $\checkmark$ & $\checkmark$ \\
\hline & 2 & $\checkmark$ & $\checkmark$ & $\checkmark$ & $x$ & $\checkmark$ & $\checkmark$ & $x$ \\
\hline & 3 & $\checkmark$ & $\checkmark$ & $x$ & $\checkmark$ & $\checkmark$ & $\checkmark$ & $\checkmark$ \\
\hline \multirow{3}{*}{ RA } & 1 & $\checkmark$ & $\checkmark$ & $x$ & $x$ & $\checkmark$ & $\checkmark$ & $\checkmark$ \\
\hline & 2 & $\checkmark$ & $\checkmark$ & $\checkmark$ & $\checkmark$ & $\checkmark$ & $\checkmark$ & $\checkmark$ \\
\hline & 3 & $\checkmark$ & $\checkmark$ & $x$ & $\checkmark$ & $\checkmark$ & $\checkmark$ & $\checkmark$ \\
\hline \multirow{3}{*}{ CPI } & 1 & $\checkmark$ & $\checkmark$ & $x$ & $x$ & $\checkmark$ & $x$ & $\checkmark$ \\
\hline & 2 & $\checkmark$ & $\checkmark$ & $\checkmark$ & $\checkmark$ & $\checkmark$ & $x$ & $x$ \\
\hline & 3 & $\checkmark$ & $\checkmark$ & $\checkmark$ & $x$ & $\checkmark$ & $x$ & $\checkmark$ \\
\hline \multirow{3}{*}{ RSP } & 1 & $\checkmark$ & $x$ & $x$ & $x$ & $\checkmark$ & $x$ & $x$ \\
\hline & 2 & $\checkmark$ & $x$ & $x$ & $x$ & $\checkmark$ & $x$ & $x$ \\
\hline & 3 & $\checkmark$ & $x$ & $x$ & $x$ & $\checkmark$ & $x$ & $x$ \\
\hline
\end{tabular}

Information:

$\checkmark$ : Appear

$x:$ Not Appear

\subsection{First Indicator}

The first indicator is to present mathematical statements orally, in writing, pictures and diagrams. All subjects were able to fulfill this indicator in all three questions. This indicator expects the subject to understand the problem by writing down the information available and explaining the meaning of the information orally.

\footnotetext{
D. Dik: Tkakek/andi $(y)$

Nrvi $(x)$

Umur Nurvl 3 tahun yg lalv $=\frac{1}{6}$ umur kakek $\Rightarrow x-3=\frac{1}{6} y$

Umur Nrul 21 thn yg:akan dig $=\frac{1}{3}$ umur kakek $\Rightarrow x+21=\frac{1}{3} y$

Dit: Brp umur Nurvi oumur kakek $5^{\text {thn }}$ yg okan dakang? dan apakah jumah unur nuru don kakek saak ini adlh loo tahun?
}

Figure 1 Subject RO's answer to indicator 1 question no. 1 .

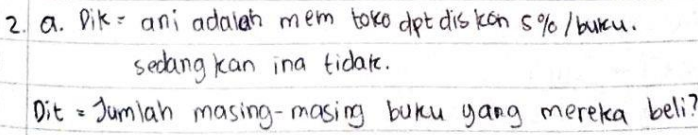

Figure 2 Subject CPI's answer to indicator 1 question no. 2 .
3. Diketahui : keliling $A B D$ adulah $72 \mathrm{~cm}$. Keliling $A B C$ adalah $96 \mathrm{~cm}$ $A B=24 \mathrm{~cm} \quad O C=14$ $C B=4 / 3 y \quad D B=y$.
Ditanya: selisin was seginga $A B C$ dan $A B D$ ?

Figure 3 Subject AS's answer to indicator 1 question no. 3 .

Figures 1, 2 and 3 show the answers of the subjects on indicator 1 in writing. However, there were also other subjects who had not written the information but were able to state the information verbally during the interview. When interviewing, all subjects are able to state what information is available and explain the purpose of the information.

\subsection{Second Indicator}

The second indicator is proposing an assumption. This indicator expects students to be able to formulate arguments and strategies to determine the steps for completion and the elements used. To answer the questions given, this indicator requires students to be able to form an equation model of the problem and determine the method used to solve it. Most of the subjects met this indicator but there was 1 subject who still could not make his guesses correctly.

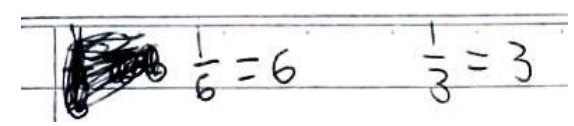

Figure 4 RSP's answer to indicator 2 question no. 1.

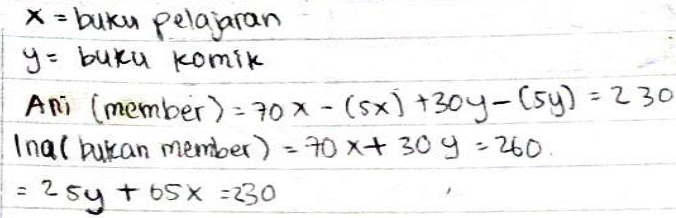

Figure 5 CPI's answer to indicator 2 question no. 2. 


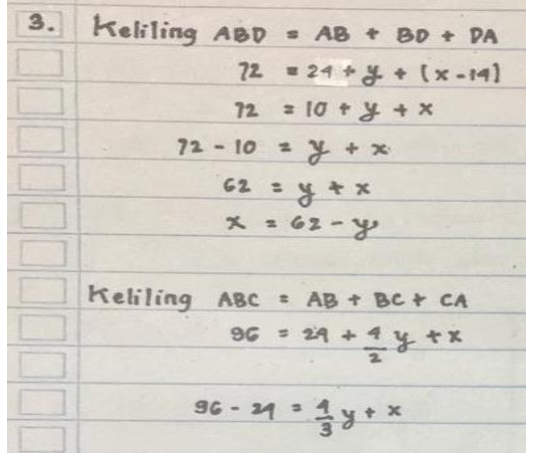

Figure 6 RO's answer to indicator 2 question no. 3.

Figure 4 shows that RSP subject has not been able to formulate a strategy to solve the problem. Problem 1 asks students to make mathematical models in the form of fractions. To facilitate the counting process, almost all students change the form into whole numbers. The following are the results of interviews with RSP.

$$
\begin{aligned}
& R \quad: \text { "here you answer } \frac{1}{6}=6 \text {, what does that } \\
& \text { meaning?" } \\
& R S P: \text { "I mean that } \frac{1}{6} \text { if used as a regular number is } \\
& \quad \text { equal to 6" } \\
& \quad: \text { "why is that?" } \\
& R S P: \text { "as I remember learning like that, Miss", }
\end{aligned}
$$

From the interview, it can be seen that RSP has not yet understood the concept of the material and has not even understood number operations. Even though this concept is the basis for understanding the SPLDV material.

Figures 5 and 6 shows that the subject fulfills the $2^{\text {nd }}$ indicator by making mathematical models. They are able to assume the variables and determine the equations of a given situation.

\subsection{Third Indicator}

The third indicator is perform mathematical manipulation. This indicator requires students to use certain methods in solving problems. Researchers taught 3 SPLDV completion methods and students can use one of the three methods or their own method and determine the most effective method. However, on this indicator some subjects are still not fulfilled. Even though there are those who can do it well, there are still many subjects who find it difficult to work on these questions.

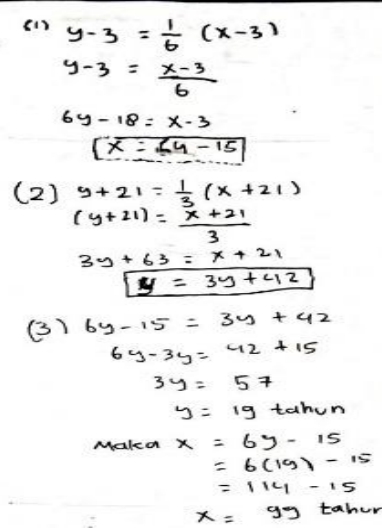

Figure 7 DKJ's answer to indicator 3 question no. 1.

Ina bukan momber buku menseluarkan
sebesar 260.000
$j$ - buku pelajaran $=140.000$
J buku novel $=120.000$

Figure 8 RSP 's answer to indicator 3 question no. 2.

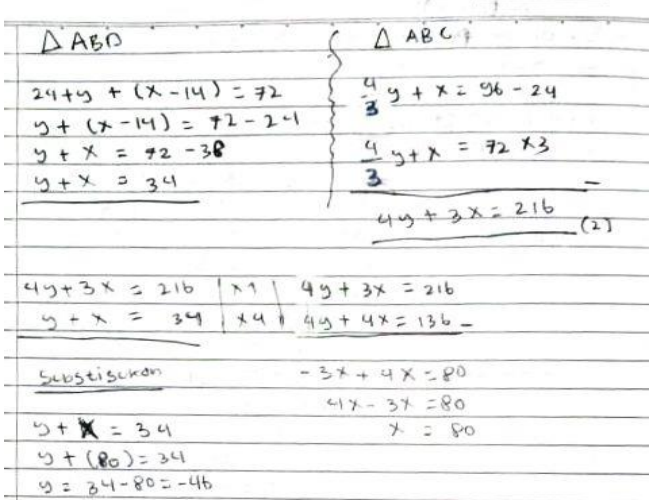

Figure 9 DKJ's answer to indicator 3 question no. 3.

Figure 7 shows the DKJ's answer, which is the only subject who answered correctly and met the 3rd indicator in question number 1 . DKJ used a method other than the 3 methods taught. He made 2 mathematical models in the form of the $\mathrm{x}$ equation to produce a value for $\mathrm{y}$ then substituted it for the value $\mathrm{x}$.

Figure 8 shows that RSP has not been able to perform mathematical manipulation. He answered correctly that the number of textbooks was 2 and the comics was 4, but he did not write down the steps to solve them. The following is an excerpt from the interview with RSP.

$R \quad$ : "this question is asked for comic, why are you looking for the price of a novel?"

RSP : "oh yes, I wrote it wrong Miss.

$R \quad$ : "okay, no problem. Where do you get 2 and 4 from?"

RSP : "by trial and error, Miss. It is known that the price that Ani issued was IDR 230.000. then try it, for example, how many textbooks, how many comics, if you add up the result is IDR 
230.000. so I get the textbooks 2 and comics 4."

\section{$R \quad:$ 'how about Ina?'”}

RSP : "same, just try it. But there is no discount so the price is normal"

It can be seen that RSP actually understand the meaning of the questions but has not been able to use certain methods to solve these problems. He did not even pay attention to the information in the questions that Ani and Ina buy the same number of books so that if you get Ani's number then you do not need to look for Ina's. This is because RSP still does not understand the material given.

Figure 9 shows that the DKJ has been able to use the method to solve these problems. But, DKJ is not precise when perfoming subtraction operations in equation 1 . In the $y+(x-14)=72-24$ part it should produce $y+x=62$, but it adds up like this: $y+(x-14)=$ $72-24 \rightarrow y+x=72-(24+14) \rightarrow y+x=$ $72-38$ so that $\mathrm{y}+x=34$ results in the wrong equation. DKJ is an active subject during learning and does not seem to have any difficulties. In the interview, DKJ admits that he is wrong in the concept of addition and realizes that the answer is wrong until the end. This means that DKJ understands the concepts and procedures of the work, but is not thorough in doing it.

\subsection{Fourth Indicator}

The fourth indicator is drawing conclusions, compiling evidence, providing reasons or evidence for the correctness of the solution. This indicator expexts students to be able to use and show a predetermined strategy in carrying out the completion steps appropriately. This means that students must understand every step of their work. On this indicator, half of the subjects have fulfilled it. This indicator is seen at the time of the interview by asking questions such as "how could it be like this?" and some subjects can explain their answer but some are still confused about their own answers which indicates they still do not understand their answers.

\subsection{Fifth Indicator}

The fifth indicator is drawing conclusions from the statement. This indicator expects student to be able to make conclusions or use their knowledge to produce a thought in accordance with the problem. This means that students do not just work on the problem but also understand the direction and purpose of the question. On this indicator, all subjects meet in every question.

\section{Jadi, Jumlah umur kaket dan Nurul $\neq 100$ tahun}

Figure 10 Subject RO's answer to indicator 5 question no. 1.

Serisin $\begin{aligned} & \angle A B C \text { dengon } \angle \triangle \triangle B D=\angle D B C-\angle D A B D \\ &=384-216 \\ &=168 \mathrm{~cm}^{2} \\ & \text { sorrss } \angle A A B C \text { dengun } \angle A A B C \text { ddalah } 168 \mathrm{~cm}^{2}\end{aligned}$

Figure 11 Subject RA's answer to indicator 5 question no. 3 .

$$
\begin{aligned}
& \text { judi selisih duas segitiga } A B C \text { dan segitiga } A B D \text { adalah } \\
& 384 \mathrm{~cm}^{2}-216 \mathrm{~cm}^{2}=168 \mathrm{~cm}^{2} .
\end{aligned}
$$

Figure 12 Subject AS's answer to indicator 5 question no. 3 .

\subsection{Sixth Indicator}

The 6th indicator is checking the correctness of an argument. This indicator expects students to be able to reexamine the problem and investigate the truth of the statements they have made. Those who fulfill this indicator are subjects with high ability and moderate ability. Low ability subjects were still confused when asked whether they were sure of the answer. This indicator is shown through interviews with researchers because none of them wrote down the steps to check the truth in their answers. The following is an excerpt from the interview with the subject.

$R \quad$ : "In question number 2, you answered 2 for textbooks and 4 for comics, right?"

AS : "Yes, Miss"

$R \quad$ : "How can you be sure that this answer is correct?"

AS : "2 and 4 are included in the equation with the variables, Miss. Which is 70.000x+ $30.000 y=260.000 "$

It appears that AS has been able to account for the answer and sure that the answer is correct by substituting the value obtained for each existing equation.

\subsection{Seventh Indicator}

The 7th indicator is finding patterns or properties of mathematical symptoms to make generalizations. This indicator expects students to be able to find patterns or properties of a problem and can be used to solve new situations so that students are able to draw valid conclusions. In this study, reseachers provide other situations in each question so that when students have 
obtained a solution, they can use the solution to solve other existing situations. Half of the subjects met this indicator and half were unable.

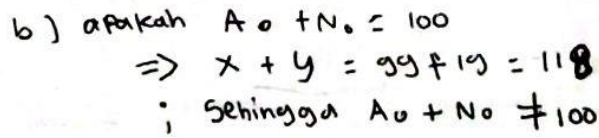

Figure 13 Subject DKJ's answer to indicator 7 question no. 1.

$\begin{aligned} \text { B. Ani } & =65.000-5 \% \\ & =65.000-(5 \% \times 65.000) \\ & =65.000-3.200 \quad \\ & =\$ 1.750\end{aligned}$

Figure 14 Subject RO's answer to indicator 7 question no. 1.

Figures 13 and 14 show that the subject is able to use the $\mathrm{x}$ and $\mathrm{y}$ values they have obtained in problem (a) to solve problem (b) and make correct conclusions. For question number 3, only the RSP subject did not meet this indicator because he was wrong on problem (a) so that it was also wrong in problem (b). At the time of the interview, he admitted that he didn't really know how to solve it.

The results showed that of the 7 indicators of mathematical reasoning ability used, the indicator that was fulfilled by all subjects was the 1st indicator, namely present oral, written, picture and diagram and the 5th indicator was drawing conclusions from the statement. While the indicator that appears the least is the 3rd indicator, which is doing mathematical manipulation.

The first indicator expects students to be able to explain the problem from the questions given, be able to determine and identify the information contained in the questions, namely knowing what is known and asked from the questions. So, students not only write down what they know and ask but are also able to explain the meaning of the information so that it shows that students really understand the problem. This indicator appears in all research subjects. Students are able to write down what they know and ask about the questions and during the interview are given in-depth questions such as "do you understand the meaning of this question?" and the researcher asked the subjects to explain in his own language the intent and purpose of the question. This can happen because students are accustomed to being taught to write information when working on math problems. This is supported by $[16,17]$ that the subject is able to understand the problem by translating the story problem into a simple form because it is implicitly accustomed to being taught by the teacher in the classroom.
Another indicator that appears in all subjects is the fifth indicator, which is to draw conclusions from statements. The subject is able to make conclusions on the problems they are working on. Even though there were some subjects who answered wrongly, they still made conclusions on their thoughts so that this indicator still emerged. This is because students are used to making conclusions when working on story problems. Likewise what was said by [31] in his research that the ability of students to draw conclusions reached a very high category because students were used to using deductive thinking, which means that in solving problems students used their experiences to strengthen reasoning which then became provisions for solving problems.

Meanwhile, the indicator that appears the least is the third indicator, which is doing mathematical manipulation. Not one subject succeeded in bringing up this indicator in the three questions, which means that at least one subject made a miscalculation in one of the questions. The subjects admitted that they had difficulty determining the mathematical model because of the problems they thought were difficult. Students also do not understand the method of elimination due to the provision of material only through instructional videos. Non-routine problems have become new to them so that many are confused about solving it, especially when there is not much time. In accordance with the definition of non-routine problems, namely problems with the solving process that do not use ordinary procedures or a problem that contains challenges in solving which require relatively longer time than routine questions $[23,32]$.

\section{CONCLUSION}

Mathematical reasoning is an important aspect of learning because with that good reasoning students are able to solve routine and non-routine problems. Students should be accustomed to working on non-routine problems so that they are accustomed to using various procedures to improve their mathematical reasoning skills so that they are able to solve problems well. Based on the results of data analysis obtained, it can be concluded that of the 7 mathematical reasoning indicators used, students with high abilities fulfill almost all reasoning indicators. Only a few indicators are not fulfilled in namely posing an assumption, perform mathematical manipulation and draw conclusions, compile evidence, provide reasons or evidence for the correctness of the solution to problem 1 and find patterns or properties of mathematical phenomena that will be generalized to problem 2. Medium ability students also meet almost all indicators. Indicators that are not fulfilled are indicators of perform mathematical manipulation on problem 1 and 3, draw conclusions, compile evidence, provide reasons or evidence for the correctness of the solution to problems number 1 and 2 then find patterns or properties of mathematical phenomena that will be 
generalized to problem 2. Students with low abilities are still not dominant in indicators of reasoning ability. They only permit indicators to present oral, written, picture and diagram math statement and draw conclusions from those statements. The indicators that appear the most are the first indicator, which is present oral, written, pictures and diagrams and the fifth indicator is drawing conclusions from the statement. While the indicator that appears the least is the third indicator, which is doing mathematical manipulation.

\section{ACKNOWLEDGMENTS}

The researcher would like to thank the validator, namely Mr. Jeri Araiku, M.Pd who always helpful in advising each instrument research. Furthermore, the researchers would like to thank SMP Negeri 17, The Principal, Mrs. Dra. Hj. Tetrayanti, M.Si, Deputy Public Relations Mrs. Emi Trisna, S.Pd., M.Si, Mathematics Teacher Mrs. Hj. Een Supriyanti, S.Pd., M.Si who has allowed and facilitated the research process there. And no less important to class VIII.7 students who have been willing to be the subjects of this research.

\section{REFERENCES}

[1] Adegoke, B.A, Modelling the relationship between mathematical reasoning ability and mathematics attainment, Journal of Education and Practice 4(17), 2013, pp 54-61.

[2] K.N. Higgins, L. Crawford, J. Huscroft-D’Angelo, M. Horney, Investigating student use of electronic support tools and mathematical reasoning Contemporary Educational Technology 7(1), 2016, pp 1-24. DOI: https://doi.org/10.30935/cedtech/6160

[3] D. Saxton, E. Grefenstette, F. Hill, P. Kohli, Analysing mathematical reasoning abilities of neural models arXiv preprint arXiv:1904.01557, 2019.

[4] O. Buchbinder, S. McCrone, Mathematical Reasoning and Proving for Prospective Secondary Teachers, Proceedings of the 21st Annual Conference of the Research in Undergraduate Mathematics Education, Special Interest Group of the Mathematical Association of America, 2018.

[5] J. Mata-Pereira, J.P da Ponte, Enhancing students' mathematical reasoning in the classroom: teacher actions facilitating generalization and justification, Educational Studies in Mathematics 96(2), 2017, pp 169-186. DOI: https://doi.org/10.1007/s10649-0179773-4

[6] K. Brodie, Teaching mathematical reasoning in secondary school classrooms (Vol. 775) Springer Science \& Business Media, 2009.
[7] J. Sidenvall, J. Lithner, J. Jäder, Students' reasoning in mathematics textbook task-solving International journal of mathematical education in science and technology 46(4), 2015, pp 533-552. DOI: https://doi.org/10.1080/0020739X.2014.992986

[8] Kemendikbud, Peraturan Menteri Pendidikan dan Kebudayaan Republik Indonesia Nomor 21 Tahun 2016 (Jakarta: Kementerian Pendidikan dan Kebudayaan), 2016.

[9] B. I. Yusdiana, W. Hidayat, Analisis Kemampuan Penalaran Matematis Siswa SMA pada Materi Limit Fungsi JPMI (Jurnal Pembelajaran Matematika Inovatif) 1(3), 2018, pp.409-414. DOI: http://dx.doi.org/10.22460/jpmi.v1i3.p409-414

[10] M. Chinnappan, Relationship between scientific reasoning skills and mathematics achievement among Malaysian students, Geografia-Malaysian Journal of Society and Space, 12(1), 2017.

[11] D. Fisher, Y. S. Kusumah, J. A. Dahlan, Junior High School Students' Mathematical Reasoning Ability Analysis in Systems of Linear Equations and Applications, Journal of Physics: Conference Series (Vol. 1315, No. 1, p. 012044) IOP Publishing, 2019.

[12] A. Davidson, S. Herbert, L. A. Bragg, Supporting Elementary Teachers' Planning and Assessing of Mathematical Reasoning, International Journal of Science and Mathematics Education 17(6), 2019, pp. 1151-1171. DOI: https://doi.org/10.1007/s10763-018-9904-0

[13] T. Setiawati, D. Muhtadi, D. Rosaliana, Kemampuan Penalaran Matematis Siswa pada Soal Aplikasi Prosiding Seminar Nasional \& Call For Papers, 2019.

[14] A. Rizta, Z. Zulkardi, Y. Hartono Y 2013 Pengembangan Soal Penalaran Model TIMSS Matematika SMP, Jurnal Penelitian dan Evaluasi Pendidikan 17(2), 2013, pp.230-240. DOI: https://doi.org/10.21831/pep.v17i2.1697

[15] T. Mulyati, Kemampuan pemecahan masalah matematis siswa sekolah dasar EduHumanioral Jurnal Pendidikan Dasar Kampus Cibiru 3(2), 2016. DOI: https://doi.org/10.17509/eh.v3i2.2807

[16] N. A. Safura, N. Aisyah, C. Hiltrimartin, Indaryanti, Student's Mathematical Value in Mathematics Learning using Non-Routine Problem, Jurnal Cakrawala Pendidikan 37, no. 3, 2018, DOI: https://doi.org/10.21831/cp.v38i3.19032

[17] A. Amka, Problem Solving-Based Learning on Systems of Linear Equation in Three Variables at SMA Srijaya Negara Palembang, International 
Journal of Innovation, Creativity and Change Vol. 11, Issue 6, 2020.

[18] W. Widada, D. Herawaty, M. H. Rahman, et al., Overcoming the difficulty of understanding systems of linear equations through learning ethnomathematics Journal of Physics: Conference Series (Vol. 1470, No. 1, p. 012074) IOP Publishing, 2020.

[19] R. R. Pulungan, Analysis of student's misconception in solving system of linear equation in two variables Journal of Physics: Conference Series (Vol. 1157, No. 4, p. 042113) IOP Publishing, 2019.

[20] J. Juliana, Pemahaman Siswa Terhadap Konsep Sistem Persamaan Linear Dua Variabel (SPLDV) Jurnal Seminar Nasional Matematika dan Pendidikan Matematika UNY, 2017.

[21] F. Ferdianto, L. Yesino, Analisis kesalahan siswa dalam menyelesaikan soal pada materi SPLDV ditinjau dari indikator kemampuan matematis, SJME (Supremum Journal of Mathematics Education) Vol.3, No.1, 2019, pp. 32-36. DOI: https://doi.org/10.35706/sjme.v3i1.1335

[22] M. Indrawati, Deskripsi Kemampuan Penalaran Matematis Dalam Menyelesaikan Soal Non Rutin Siswa Smp Gunungjati Kembaran (Doctoral Dissertation, Universitas Muhammadiyah Purwokerto), 2019.

[23] H. Hartatiana, Pengembangan soal pemecahan masalah berbasis argumen untuk siswa kelas $\mathrm{V}$ di SD Negeri 79 Palembang, Jurnal Pendidikan Matematika JPM 8(02), 2014, pp.76-85.

[24] National Council of Teachers of Mathematics, Principles and standards for school mathematics Reston VA: NCTM, 2000.

[25] N. Aisyah, Pendekatan pemecahan masalah matematika. Online) Diperoleh dari www. staff. uny. ac. id. pengembangan pembelajaran matematika. Diakses 20, 2011.

[26] S. Fadillah, Kemampuan Pemecahan Masalah Matematis dalam Pembelajaran Matematika, Seminar Nasional Penelitian, Pendidikan dan Penerapan MIPA, 2009, pp. 553558.

[27] P. Wang, S. Mou, J. Lian, W. Ren, Solving a system of linear equations: From centralized to distributed algorithms Annual Reviews in Control 47, 2019, pp 306-322.

DOI: https://doi.org/10.1016/j.arcontrol.2019.04.008
[28] S. Pengmanee, Developing students' mathematical reasoning ability based on constructivist approach, Journal of Advances in Humanities and Social Sciences 2(4), 2016, pp 221-231. DOI: https://doi.org/10.20474/jahss-2.4.3

[29] A. Putri, Analisis Kemampuan Pemecahan Masalah Rutin dan Non-Rutin pada Materi Aturan Pencacahan, Jurnal Pendidikan Tambusai 2(2), 2018, pp 890-896. DOI: https://doi.org/10.31004/jptam.v2i4.38

[30] F. Andayani, A. N. Lathifah, Analisis kemampuan pemecahan masalah siswa smp dalam menyelesaikan soal pada materi aritmatika sosial, Jurnal Cendekia: Jurnal Pendidikan Matematika 3(1), 2019, pp 1-10. DOI: https://doi.org/10.31004/cendekia.v3i1.78

[31] T. Indriani, A. Hartoyo, D. Astuti, Kemampuan penalaran adaptif siswa dalam memecahkan masalah kelas VIII SMP Pontianak Jurnal Pendidikan dan Pembelajaran Khatulistiwa, 6(2), 2017.

[32] T. Evans, M. O. Thomas, S. Klymchuk, Non-routine problem solving through the lens of self-efficacy Higher Education Research \& Development, 2020, pp 1-18. DOI: https://doi.org/10.1080/07294360.2020.1818061 